\title{
Analysis Of The Influence Of Service Quality On Customer Satisfaction In PT. Summit Oto Finance Branch Of Surabaya
}

\author{
Eni Yuli Siswati and Agus Sukoco \\ Program Studi Manajemen, Fakultas Ekonomi Dan Bisnis \\ Universitas Narotama Surabaya \\ Email autor: agus.sukoco@ narotama.ac.id
}

\begin{abstract}
Abstrak
This study aims to determine and analyze how much influence the quality of services on the level of satisfaction felt by customers who use the financing services of PT Summit Oto Finance Surabaya Branch. The model used in this research is the method of observation, interviews, and questionnaires using a Likert scale and the method of determining the sample used is Proportionate Stratified Random Sampling of 100 samples. The analytical method used is the multiple linear regression method (Multi Linear Regression. The results of the study obtained the regression equation $\mathrm{Y}=0.408+0.035 \mathrm{X} 1+0.320 \mathrm{X} 2+0.183 \mathrm{X} 3+0.217 \mathrm{X} 4+0.277 \mathrm{X} 5$. Where simultaneously all variables are tangible, reliability, responsiveness, assurance., and empathy have a significant influence and positive direction of the relationship on customer satisfaction, while partially only tangible variables that do not affect customer satisfaction The most influencing variable on customer satisfaction is the variable reliability $(2,898)$.
\end{abstract}

Keyword:

Service quality, customer satisfaction, tangible, reliability, responsiveness, assurance, empathy

\section{Pendahuluan \\ 1.1.Latar Belakang}

Kebutuhan masyarakat saat ini akan sepeda motor yang berbenturan dengan daya beli masyarakat merangsang didirikannya perusahaan-perusahaan pembiayaan sepeda motor. Salah satunya adalah PT Summit Oto Finance.

PT Summit Oto Finance Cabang Surabaya merupakan salah satu perusahaan finance yang bergerak di bidang pembiayaan sepeda motor baik Honda, Yamaha, Suzuki, Kawasaki, Piaggio, serta Bajaj. Berada dalam satu group dengan perusahaan PT Oto Multiartha, di bawah dukungan dana dari Sumitomo Corporation, Japan. PT Summit Oto Finance mampu berkembang dengan cukup pesat, dan meskipun tergolong perusahaan pembiayaan baru, PT Summit Oto Finance sudah mampu menjadi kompetitor yang cukup disegani dalam industri pembiayaan.

Pada dasarnya setiap perusahaan mengarahkan tujuannya untuk memperoleh keuntungan yang optimal dan menjalankan operasi bisnis perusahaan secara berkesinambungan dan mencapai visi yang telah ditetapkan. Namun, di era globalisasi saat ini tidaklah mudah, mengingat semakin banyaknya perusahaan yang bergerak dalam bidang yang sama, dan dengan tujuan yang sama, serta dengan produk dan jasa yang sama. Dengan semakin ketatnya persaingan dalam bidang pembiayaan, setiap perusahaan dituntut untuk senantiasa memperhatikan kebutuhan dan keinginan pelanggan serta berusaha memenuhi harapan pelanggan dengan cara memberikan pelayanan yang lebih berkualitas dibandingkan dengan kompetitor.

Seiring dengan perkembangan ekonomi yang pesat dan menjamurnya perusahaan pembiayaan yang menawarkan jasa dan produk yang sama menyebabkan perkembangan pola pikir masyarakat dari yang sebelumnya hanya berfokus pada mutu produk menjadi lebih cerdas, dengan memperhatikan aspek lain dari perusahaan penyedia jasa, yaitu pelayanan yang prima dan berkualitas. Hal ini menjadikan kualitas pelayanan sebagai pertimbangan yang cukup mempengaruhi konsumen dalam menentukan produk/ jasa dari perusahaan mana yang akan mereka pilih. Dengan meningkatnya kualitas pelayanan dari perusahaan, diharapkan akan menciptakan kepuasan bagi para konsumen. Setelah konsumen merasa puas dengan jasa dan pelayanan yang diterima, mereka akan cenderung membandingkan kualitas yang diberikan oleh PT Summit Oto Finance dengan perusahaan pembiayaan lain. Dan jika konsumen merasa pelayanan yang diberikan oleh PT Summit Oto Finance adalah lebih baik, maka kemungkinan besar konsumen akan memberikan loyalitasnya kepada PT Summit Oto Finance untuk tetap menggunakan PT Summit Oto Finance sebagai partner pembiayaannya di masa-masa mendatang. Bahkan nilai plus nya adalah, konsumen akan melakukan promosi mouth to mouth yang dengannya akan mampu meningkatkan market PT Summit Oto Finance. 
Ringkasnya, faktor pelayanan akan dapat menimbulkan nilai pelanggan yang akhirnya tidak hanya akan berwujud pada nilai kepuasan pelanggan saja, tetapi juga berpengaruh terhadap loyalitas pelanggan sebagai tahap akhir. Sehingga perusahaan pembiayaan akan dapat mempertahankan pelanggan dan menambah marketnya secara terus menerus. Lebih dari itu, kepuasan pelanggan kemudian dijadikan sebagai tolok ukur keunggulan daya saing perusahaan.

\subsection{Perumusan Masalah}

Berdasarkan uraian latar belakang tersebut di atas, Penulis mengajukan rumusan masalah sebagai berikut:

1. Apakah kualitas pelayanan yang terdiri dari tangible, reliability, responsiveness, assurance, dan empathy berpengaruh signifikan secara simultan terhadap kepuasan pelanggan PT. Summit Oto Finance Cabang Surabaya?

2. Apakah kualitas pelayanan yang terdiri dari tangible, reliability, responsiveness, assurance, dan empathy berpengaruh signifikan secara parsial terhadap kepuasan pelanggan PT. Summit Oto Finance Cabang Surabaya?

\subsection{Tujuan Penelitian}

Mengacu pada perumusan masalah di atas, maka tujuan dari penelitian ini adalah :

1. Untuk mengetahui pengaruh secara simultan kualitas pelayanan yang terdiri dari tangible, reliability, responsiveness, assurance, dan empathy terhadap kepuasan pelanggan PT. Summit Oto Finance Cabang Surabaya.

2. Untuk mengetahui pengaruh secara parsial kualitas pelayanan yang terdiri dari tangible, reliability, responsiveness, assurance, dan empathy terhadap kepuasan pelanggan PT. Summit Oto Finance Cabang Surabaya.

\section{Tinjauan Pustaka \\ 2.1.Kajian Teoritis \\ 2.1.1.Pengertian Jasa}

Jasa adalah setiap tindakan atau kegiatan yang dapat ditawarkan oleh satu pihak kepada pihak lain, yang pada dasarnya tidak berwujud dan tidak mengakibatkan kepemilikan apapun. Produksinya dapat dikaitkan atau tidak dikaitkan dengan suatu produk fisik. (Kotler, 2002: 486).

Jasa adalah proses yang terdiri atas serangkaian aktivitas intangible yang biasanya (namun tidak harus selalu) terjadi pada interaksi antara pelanggan dan karyawan jasa dan atau sumber daya fisik atau barang atau sistem penyedia jasa, yang disediakan sebagai solusi atas masalah pelanggan. (Fandy Tjiptono dan Gregorius Chandra, 2007: 11)

Jasa merupakan pemberian suatu kinerja atau tindakan tak kasat mata dari satu pihak kepada pihak lain. Pada umumnya jasa diproduksi dan dikonsumsi secara bersamaan, dimana interaksi antara pemberi jasa dan penerima jasa mempengaruhi hasil jasa tersebut. (Rangkuti, 2003:90)

Jasa adalah tindakan atau kinerja yang menciptakan manfaat bagi pelanggan dengan mewujudkan perubahan yang diinginkan dalam diri—atau atas nama - penerima jasa tersebut. (Lovelock dan Wright, 2005:5)

Jadi pada dasarnya jasa merupakan semua aktivitas ekonomi yang hasilnya tidak merupakan produk dalam bentuk fisik atau konstruksi, yang biasanya dikonsumsi pada saat yang sama dengan waktu yang dihasilkan dan memberikan nilai tambah (seperti misalnya kenyamanan, hiburan, kesenangan, atau kesehatan) atau pemecahan atas masalah yang dihadapi oleh konsumen.

\subsubsection{Kualitas Jasa atau Pelayanan}

Service Quality dapat didefinisikan sebagai seberapa jauh perbedaan antara kenyataan dan harapan para pelanggan atas layanan yang mereka terima. Menurut Tjiptono (2005: 121), kualitas jasa adalah tingkat keunggulan yang diharapkan dan pengendalian atas tingkat keunggulan untuk memenuhi keinginan pelanggan.Dimensi Kualitas Jasa:

1. Tangibles, atau bukti fisik yaitu kemampuan suatu perusahaan dalam menunjukkan eksistensinya kepada pihak eksternal. Penampilan dan kemampuan sarana dan prasarana fisik perusahaan dan keadaan lingkungan sekitarnya adalah bukti nyata dari pelayanan yang diberikan oleh pemberi jasa.Karena suatu bentuk jasa tidak bisa dilihat, tidak bisa dicium, dan tidak bisa diraba maka aspek wujud fisik menjadi begitu penting sebagai ukuran dari pelayanan. Pelanggan akan menggunakan indra penglihatan untuk menilai kualitas suatu pelayanan. Bukti fisik merupakan pemenuhan kebutuhan konsumen yang berfokus pada fasilitas fisik seperti gedung dan ruangan, kebersihan, kerapian dan kenyamanan ruangan, sarana komunikasi, fasilitas penunjang, serta penampilan karyawan (Lupiyoadi dan Hamdani, 2006:181).

Atribut-atribut yang ada pada dimensi ini adalah sebagai berikut : 

a. Peralatan modern.
b. Fasilitas yang berdaya tarik visual.
c. Karyawan yang berpenampilan rapi dan profesional.

2. Reliability, atau keandalan yaitu kemampuan perusahaan untuk memberikan pelayanan sesuai dengan yang dijanjikan secara akurat dan terpercaya.Kinerja harus sesuai dengan harapan pelanggan yang berarti ketepatan waktu, pelayanan yang sama untuk semua pelanggan tanpa kesalahan, sikap yang simpatik dan dengan akuisisi yang tinggi.

Atribut-atribut yang ada dalam dimensi ini adalah sebagai berikut :

a. Menyediakan jasa sesuai yang dijanjikan

b. Menyampaikan jasa dengan benar semenjak pertama kali

c. Menyimpan catatan/ dokumen tanpa kesalahan

3. Responsiveness, atau daya tanggap yaitu kemampuan perusahaan untuk membantu dan memberikan pelayanan yang cepat (responsif) dan tepat kepada pelanggan dengan penyampaian informasi yang jelas.

Atribut-atribut yang ada dalam dimensi ini adalah sebagai berikut :

a. Menginformasikan pelanggan tentang kepastian waktu penyampaian jasa

b. Layanan yang segera/cepat bagi pelanggan

c. Kesiapan untuk merespon permintaan pelanggan

4. Assurance, atau jaminan dan kepastian yaitu pengetahuan, kesopansantunan, dan kemampuan para pegawai perusahaan untuk menumbuhkan rasa percaya pelanggan kepada perusahaan sehingga bebas dari bahaya, resiko ataupun keraguan. Maksudnya adalah karyawan benar-benar mengetahui produk perusahaan, senantiasa sopan dalam memberikan pelayanan, memiliki keterampilan dalam memberikan informasi, hingga kemampuan dalam memberikan keamanan dan menanamkan rasa kepercayaan dan keyakinan konsumen terhadap perusahaan.

Atribut-atribut yang ada dalam dimensi ini adalah sebagai berikut :

a. Karyawan yang menumbuhkan rasa percaya para pelanggan.

b. Membuat pelanggan merasa aman saat menggunakan jasa pelayanan yang diberikan.

c. Karyawan yang secara konsisten bersikap sopan.

5. Empathy, yaitu memberikan perhatian yang tulus dan bersifat individual atau pribadi dengan tujuan agar dapat megetahui dan memahami keinginan pelanggan. Pemberian perhatian tersebut dapat berupa kemudahan konsumen dalam menghubungi perusahaan atau berkomunikasi langsung dengan karyawan untuk menyampaikan keinginan dan kebutuhan mereka. Dengan adanya komunikasi yang baik dan perhatian khusus akan berpengaruh pada kepuasan, karena konsumen merasa kebutuhan dan keluhan mereka ditanggapi dengan baik oleh perusahaan.

Atribut-atribut yang ada dalam dimensi ini adalah sebagai berikut :

a. Memberikan perhatian individual kepada para pelanggan

b. Karyawan memahami kebutuhan pelanggan

c. Perusahaan bersungguh-sungguh memperhatikan kepentingan pelanggan.

\subsubsection{Kepuasan Pelanggan/ Konsumen}

Kepuasan pelanggan merupakan perasaan senang atau kecewa seseorang yang muncul setelah membandingkan kinerja (hasil) produk yang dirasakan terhadap kinerja (hasil) yang diharapkan. Jika kinerja berada di bawah harapan, pelanggan tidak puas. Jika kinerja melebihi harapan, pelanggan amat puas atau senang. (Kotler, 2007:177)

Kepuasan pelanggan merupakan respon pelanggan terhadap ketidaksesuaian antara tingkat kepentingan sebelumnya dan kinerja aktual yang dirasakan setelah pemakaian. Rangkuti (2003:30)

Dari kedua pendapat tersebut, dapat disimpulkan bahwa definisi dari kepuasan pelanggan adalah respon yang ditunjukkan oleh pelanggan setelah membandingkan antara kinerja atau hasil yang dirasakan dengan harapan. Dengan demikian, harapan dan persepsi pelanggan menjadi salah satu hal yang sangat menentukan kepuasan mereka terhadap suatu pelayanan.

Menurut Kotler (2007:179) beberapa ciri konsumen yang dapat dikatakan puas adalah sebagai berikut :

1. Loyal terhadap perusahaan

Konsumen yang puas cenderung loyal terhadap suatu produk, dimana mereka akan membeli ulang dari produsen yang sama.

2. Adanya komunikasi dari mulut ke mulut yang bersifat positif

Komunikasi dari mulut ke mulut (Word of mouth communication) yang bersifat positif yaitu rekomendasi kepada calon konsumen lain dan mengatakan hal-hal yang baik mengenai produk dari perusahaan.

3. Kurang memberikan perhatian kepada merek lain dan kurang sensitif pada harga.

Ketika konsumen ingin membeli produk yang lain, maka perusahaan yang telah memberikan kepuasan kepadanya akan menjadi pertimbangan utama. Adapun harga tidak lagi menjadi pertimbangan utama konsumen karena mereka telah mengetahui kualitas dari produk perusahaan. 
Kuswadi (2004:17) menyampaikan bahwa kepuasan pelanggan dipengaruhi oleh beberapa hal, yaitu :

1. Mutu produk atau jasa

Mutu produk atau jasa yaitu mengenai mutu produk atau jasa yang lebih bermutu dilihat dari fisiknya.

2. Mutu pelayanan

Berbagai jenis pelayanan akan selalu dikritik oleh pelanggan, tetapi bila pelayanan memenuhi harapan pelanggan maka secara tidak langsung pelayanan dikatakan bermutu.

3. Harga

Harga adalah hal yang paling sensitif untuk memenuhi kebutuhan konsumen. Konsumen akan cenderung memilih produk atau jasa yang memberikan penawaran harga lebih rendah dari yang lain dengan kualitas yang tidak berbeda jauh.

4. Waktu penyerahan

Dalam hal ini maksudnya bahwa baik pendistribusian maupun penyerahan produk atau jasa dari perusahaan bisa tepat waktu dan sesuai atau bahkan lebih cepat dari perjanjian yang telah disepakati.

5. Keamanan

Pelanggan akan merasa lebih puas bila produk atau jasa yang digunakan ada jaminan keamanannya yang tidak membahayakan konsumen tersebut.

\section{Metode Penelitian}

Penelitian ini merupakan penelitian dengan pendekatan kuantitatf, yakni metode penelitian yang berlandaskan pada filsafat positivisme, digunakan untuk meneliti pada populasi atau sampel tertentu, teknik pengambilan sampel pada umumnya dilakukan secara random, pengumpulan data menggunakan instrumen penelitian, analisis data bersifat kuantitatif/ statistik dengan tujuan untuk menguji hipotesis yang telah ditetapkan. (Sugiyono, 2006:14)

\subsection{Populasi dan Sampel}

Dalam bukunya, Sugiyono (2006:90) menyatakan bahwa populasi adalah wilayah generalisasi yang terdiri atas subjek dan objek yang mempunyai kualitas dan karakteristik tertentu yang ditetapkan oleh peneliti untuk dipelajari dan kemudian ditarik kesimpulannya. Dalam penelitian ini, populasi berjumlah 30,211 orang customer dimana data tersebut bersumber dari jumlah account active PT Summit Oto Finance per Maret 2014.

Sampel merupakan bagian dari jumlah dan karakteristik yang dimiliki oleh populasi tersebut (Sugiyono, 2006:91). Penentuan jumlah sampel dalam penelitian dilakukan dengan menggunakan rumus Slovin (Umar 2005:108), dan didapatkan jumlah sampel sebanyak 100 orang.

Dalam penelitian ini digunakan strata berdasarkan usia sampel karena usia merupakan hal yang cukup penting dalam penilaian kualitas suatu pelayanan. Bagi sampel, usia menjadi salah satu faktor penyebab perbedaan selera seseorang terhadap suatu pelayanan (Fandy Tjiptono dan Gregorius Chandra, 2007:128). Dari data PT Summit Oto Finance Cabang Surabaya didaparkan jumlah sampel untuk kelompok usia 21-25 tahun sebanyak 11 orang, 26-30 tahun sebanyak 25 orang, 31-35 tahun sebanyak 27 orang, 36-40 tahun sebanyak 21 orang, dan di atas 40 tahun sebanyak 16 orang.

\subsection{Sumber Data}

\subsubsection{Data Primer}

Data primer adalah data yang dikumpulkan secara langsung dari responden yang berupa kuesioner ataupun sesi wawancara.

\subsubsection{Data Sekunder}

Data sekunder adalah data yang diperoleh melalui perusahaan dan sumber lainnya. Data sekunder didapatkan melalui :

1. Dokumen-dokumen perusahaan yang ada hubungannya dengan penyusunan penulisan ini.

2. Wawancara dengan beberapa karyawan PT Summit Oto Finance.

3. Literatur, yakni diktat atau buku-buku yang tersedia di perpustakaan yang pembahasannya sesuai dengan masalah yang dihadapi. 
Tabel 1. Desain Instrumen Penelitian

\begin{tabular}{|c|c|c|c|c|}
\hline $\begin{array}{l}\text { Variabel } \\
\text { Penelitian }\end{array}$ & $\begin{array}{l}\text { Dimensi/Sub } \\
\text { Variabel }\end{array}$ & & Indikator & Skala \\
\hline \multirow[t]{10}{*}{$\begin{array}{l}\text { Kualitas jasa } \\
(\mathrm{X})\end{array}$} & Tangible $\left(\mathrm{X}_{1}\right)$ & $\begin{array}{l}1 \\
2 \\
3 \\
1\end{array}$ & $\begin{array}{l}\text { Peralatan penunjang kegiatan sehari-hari yang modern. } \\
\text { Fasilitas gedung perusahaan yang bersih dan modern. } \\
\text { Penampilan karyawan } \\
\text { Menvediakan jasa sesuai dengan vang dijanjikan. }\end{array}$ & Likert \\
\hline & \multirow[t]{2}{*}{ Reliability $\left(\mathrm{X}_{2}\right)$} & 2 & $\begin{array}{l}\text { Menyampaikan jasa dengan benar semenjak pertama } \\
\text { kali. }\end{array}$ & \multirow[t]{2}{*}{ Likert } \\
\hline & & 3 & Menyimpan catatan/ dokumen tanpa kesalahan. & \\
\hline & \multirow[t]{2}{*}{$\begin{array}{l}\text { Responsiveness } \\
\left(\mathrm{X}_{3}\right)\end{array}$} & 2 & $\begin{array}{l}\text { Menginformasikan kepada pelanggan tentang kepastian } \\
\text { waktu penyampaian jasa. } \\
\text { Cepat merespon pelanggan yang datang. }\end{array}$ & \multirow[t]{2}{*}{ Likert } \\
\hline & & 3 & $\begin{array}{l}\text { Kesiapan untuk merespon permintaan pelanggan. } \\
\text { Karyawan yang kompeten sehingga dapat menjawab }\end{array}$ & \\
\hline & Assurance $\left(\mathrm{X}_{4}\right)$ & $\begin{array}{l}2 \\
3\end{array}$ & $\begin{array}{l}\text { pertanyaan dari pelanggan dan menumbuhkan } \\
\text { kepercayaan pelanggan. } \\
\text { Memberi rasa aman kepada pelanggan dalam transaksi. } \\
\text { Sikap sopan karyawan }\end{array}$ & Likert \\
\hline & \multirow[t]{4}{*}{ Empathy $\left.\left(\mathrm{X}_{5}\right)\right)$} & 1 & $\begin{array}{l}\text { Memberikan perhatian individual kepada pelanggan. } \\
\text { Karyawan memahami kebutuhan pelanggan. } \\
\text { Perusahaan bersungguh-sungguh memperhatikan }\end{array}$ & \multirow[t]{4}{*}{ Likert } \\
\hline & & 3 & kepentingan pelanggan. & \\
\hline & & 1 & $\begin{array}{l}\text { Kualitas pelayanan PT Summit Oto Finance sesuai } \\
\text { dengan harapan pelanggan. }\end{array}$ & \\
\hline & & 2 & $\begin{array}{l}\text { Keinginan untuk kembali menggunakan jasa PT } \\
\text { Summit Oto Finance. }\end{array}$ & \\
\hline \multirow[b]{2}{*}{ Pelanggan (Y) } & & & Melakukan komunikasi mulut ke mulut yang positif & \multirow{2}{*}{ Likert } \\
\hline & & 3 & $\begin{array}{l}\text { tentang PT Summit Oto Finance dan } \\
\text { merekomendasikannya kepada teman dan kerabat. } \\
\text { Lebih memilih PT Summit Oto Finance sebagai } \\
\text { penyedia jasa meskipun harganya lebih mahal } \\
\text { dibandingkan leasing lain. }\end{array}$ & \\
\hline
\end{tabular}

\subsection{Teknik Analisis Data}

\subsubsection{Uji Kualitas Data}

1. Uji Validitas: Uji validitas digunakan untuk mengukur sah atau tidaknya suatu kuasioner. Suatu kuesioner dapat dikatakan valid jika pertanyaan-pertanyaan pada kuesioner mampu mengungkapkan sesuatu yang akan diukur oleh kuesioner tersebut. Uji validitas dilakukan dengan membandingkan $r$ hitung dengan $r$ tabel untuk degree of freedom $(d f)=n-2$ dimana $\mathrm{n}$ adalah jumlah sampel, dengan tingkat signifikansi uji satu arah sebesar 0.05 atau 5\%. Jika $r$ hitung $>r$ tabel, maka pertanyaan dikatakan valid. Sebaliknya, jika $r$ hitung $<\mathrm{r}$ tabel, maka pertanyaan dikatakan tidak valid.

2. Uji Reliabilitas: Uji reliabilitas digunakan untuk mengetahui sejauh mana suatu hasil pengukuran relatif konsisten apabila pengukuran dilakukan dua kali atau lebih, dengan kata lain, reliabilitas menunjukkan konsistensi suatu alat ukur dalam mengukur gejala yang sama. Untuk mengetahui reliabilitas kuesioner, penelitian ini menggunakan pendekatan pengukuran reliabilitas konsistensi internal dengan menghitung koefisien alpha. Jika nilai koefisien alpha $<0,6$ berarti item pengukuran tidak reliabel. Jika nilai koefisien alpha $>0,6$ berarti item pengukuran reliabel.

3. Uji Asumsi Klasik. Uji Asumsi Klasik meliputi :

a. Uji Multikolinieritas Pengujian ini bertujuan untuk melihat apakah pada model regresi ditemukan adanya korelasi antar variabel independent (Santoso, 2000:203). Jika terjadi korelasi, maka dinamakan terdapat problem multikolinieritas (Multiko). Model regresi yang baik seharusnya tidak terjadi korelasi antar variabel independent. Apabila terjadi multikolinieritas, maka salah satu variabel bebas harus dikeluarkan dari persamaan regresi tersebut. Pedoman model regresi yang bebas dari multikolinieritas adalah memiliki nilai VIF (Variance Inflation Factory) diskitar angka 1 dan nilai toleransi mendekati 1 , atau nilai VIF kurang dari 5.

b. Uji Heteroskedastisitas. Pengujian ini bertujuan untuk melihat apakah dalam sebuah model regresi terjadi ketidaksamaan varians dari residual dari satu pengamatan ke pengamatan yang lain (Santoso, 2000:208). Jika varians dari residual dari satu pengamatan ke pengamatan lain tetap, maka disebut homokedastisitas. Dan jika varians berbeda, disebut heteroskedastisitas. Model regresi yang baik 
adalah model yang bebas dari grafik scatterplot pada linier berganda. Jika tidak terlihat pola tertentu, maka persamaan regresi tersebut bebas dari gejala heterokedastisitas.

c. Uji Normalitas. Uji normalitas bertujuan untuk menguji apakah dalam sebuah model regresi, variabel dependent, variabel independent, atau keduanya mempunyai distribusi normal ataukah tidak. Model regresi yang baik adalah distribusi data normal atau mendekati normal (Santoso, 2000:212).Deteksi normalitas dalam penelitian ini adalah dengan menggunakan Normal P-P Plot of Regression Standardized Residual, dimana jika data menyebar di sekitar garis diagonal grafik dan mengikuti arah garis diagonal, maka model regresi memenuhi asumsi normalitas. Namun jika data menyebar jauh dari garis diagonal, dan/ atau tidak mengikuti arah garis diagonal, maka model regresi tidak memenuhi asumsi normalitas.

Seluruh proses analisis statistik dalam penelitian ini menggunkan alat bantu statistical program for social science (SPSS) 17.0 for windows

\subsubsection{Analisis Regresi Linear Berganda}

Analisis regresi linier berganda digunakan untuk mengetahui besarnya pengaruh tangible, reliability, responsiveness, assurance, dan empathy terhadap kepuasan pelanggan dengan menggunakan rumus regresi linier berganda seperti yang dikutip oleh Sugiyono (2006:261), yaitu : $Y=a+b_{1} X_{1}+b_{1} X_{2}+b_{3} X_{3}+b_{4} X_{4}+$ $\mathrm{b}_{5} \mathrm{X}_{5}+\mathrm{e}$.

\subsubsection{Pengujian Hipotesis}

\section{Uji Signifikansi Pengaruh Simultan (Uji F)}

Dalam penelitian ini, uji F digunakan untuk mengetahui tingkat signifikansi pengaruh variabel-variabel independen secara bersama-sama terhadap variabel dependen. Dalam penelitian ini, hipotesis yang digunakan adalah:

$\mathrm{H}_{0}$ = Variabel - variabel bebas yaitu tangible, reliability, responsiveness, assurance, dan empathy secara simultan tidak mempunyai pengaruh yang signifikan terhadap variabel kepuasan pelanggan.

$\mathrm{H}_{\mathrm{a}}$ = Variabel-variabel bebas yaitu tangible, reliability, responsiveness, assurance, dan empathy secara simultan mempunyai pengaruh yang signifikan terhadap variabel kepuasan pelanggan.

2. Uji Signifikansi Pengaruh Parsial (Uji T)

Uji T digunakan untuk menguji signifikansi hubungan antara variabel $\mathrm{X}$ dan $\mathrm{Y}$, apakah variabel $\mathrm{X}_{1}, \mathrm{X}_{2}$, $\mathrm{X}_{3}, \mathrm{X}_{4}$, dan $\mathrm{X}_{5}$ (tangible, reliability, responsiveness, assurance, dan empathy) secara terpisah atau parsial benarbenar berpengaruh terhadap variabel Y (Kepuasan pelanggan). Hipotesis yang digunakan adalah sebagai berikut:

$\mathrm{H}_{0}$ = Variabel-variabel bebas yaitu tangible, reliability, responsiveness, assurance, dan empathy secara parsial tidak mempunyai pengaruh yang signifikan terhadap variabel kepuasan pelanggan.

$\mathrm{H}_{\mathrm{a}}$ = Variabel-variabel bebas yaitu tangible, reliability, responsiveness, assurance, dan empathy secara parsial mempunyai pengaruh yang signifikan terhadap variabel kepuasan pelanggan.

\section{Hasil Dan Pembahasan}

\subsection{Deskripsi Hasil Penelitian}

Jumlah responden yang dianalisis dalam penelitian ini berjumlah 100 orang, namun dalam pengumpulan data dilakukan dengan mendistribusikan lebih dari 100 buah kuesioner. Hal ini didasarkan pada kenyataan dimana cukup banyak kuesioner yang memiliki respon tidak lengkap, atau strata usianya tidak memenuhi karakteristik responden yang sebelumnya telah ditentukan. Dari hasil kuesioner dapat diketahi karekteristik responden berdasarkan usia, jenis kelamin, serta pendapatan.

\subsection{Uji Kualitas Data}

1. Uji Validitas

Untuk jumlah sampel 100 orang dalam penelitian ini, untuk mencari $\mathrm{r}$ table diketahui $d f=\mathrm{n}-2=100-2=$ 98, dengan tingkat signifikansi untuk uji dua arah sebesar 0.05 didapat $r$ tabel sebesar 0.1966. Dengan demikian, kuesioner dikatakan valid apabila $r$ hitung nya lebih besar dari 0.1966 ( $\mathrm{r}$ tabel). Nilai $\mathrm{r}$ hitung dapat dilihat pada kolom corrected item total correlation pada hasil pengujian kuesioner.

Tabel hasil uji validitas menggunakan software SPSS menunjukkan bahwa ke-19 item mempunyai nilai $r$ hitung (corrected item total correlation) yang lebih besar dari 0.1966 ( $\mathrm{r}$ tabel). Dengan demikian seluruh indikator dari variabel kualitas pelayanan (X) dan variabel kepuasan konsumen (Y) adalah valid.

2. Uji Reliabilitas

Dalam penelitian ini pengujian reliabilitas dilakukan dengan menggunakan rumus Alpha Cronbach dengan ketentuan bahwa Jika nilai koefisien alpha $<0,6$ berarti item pengukuran tidak reliabel. Jika nilai koefisien Alpha $>0,6$ berarti item pengukuran reliabel. 
Hasil uji reliabilitas menggunakan software SPSS menunjukkan bahwa semua variabel mempunyai koefisien alpha yang lebih besar dari yang dipersyaratkan, yaitu 0.6. Dengan demikian dapat dikatakan bahwa masing-masing instrument kuesioner dari setiap variabel adalah reliabel.

3. Uji Asumsi Klasik

a. Uji Multikolinearitas

Uji multikolinearitas dimaksudkan untuk lebih mengetahui adanya hubungan yang sempurna antar variabel bebas dalam model regresi. Dikatakan tidak terjadi (bebas) multikolinearitas jika nilai VIF <5 dan nilai toleran mendekati nilai 1 .

Tabel 2. Uji Multikolinearitas

\begin{tabular}{ccccc}
\hline \multirow{2}{*}{ Variabel } & \multirow{2}{*}{ Item } & \multicolumn{2}{c}{ Collinearity Statistic } & \multirow{2}{*}{ Keterangan } \\
\cline { 3 - 4 } & & Tolerance & VIF & \\
\hline Tangible & $\mathrm{X} 1$ & 0.485 & 2.061 & Bebas Multikol \\
\hline Reliability & $\mathrm{X} 2$ & 0.379 & 2.638 & Bebas Multikol \\
\hline Responsiveness & $\mathrm{X} 3$ & 0.632 & 1.581 & Bebas Multikol \\
\hline Assurance & $\mathrm{X} 4$ & 0.415 & 2.409 & Bebas Multikol \\
\hline Empathy & $\mathrm{X} 5$ & 0.413 & 2.421 & Bebas Multikol \\
\hline
\end{tabular}

b. Uji Heterokedastisitas

Hasil uji heterokedastisitas dengan menggunakan scatterplot menunjukkan hasil sebagai berikut:

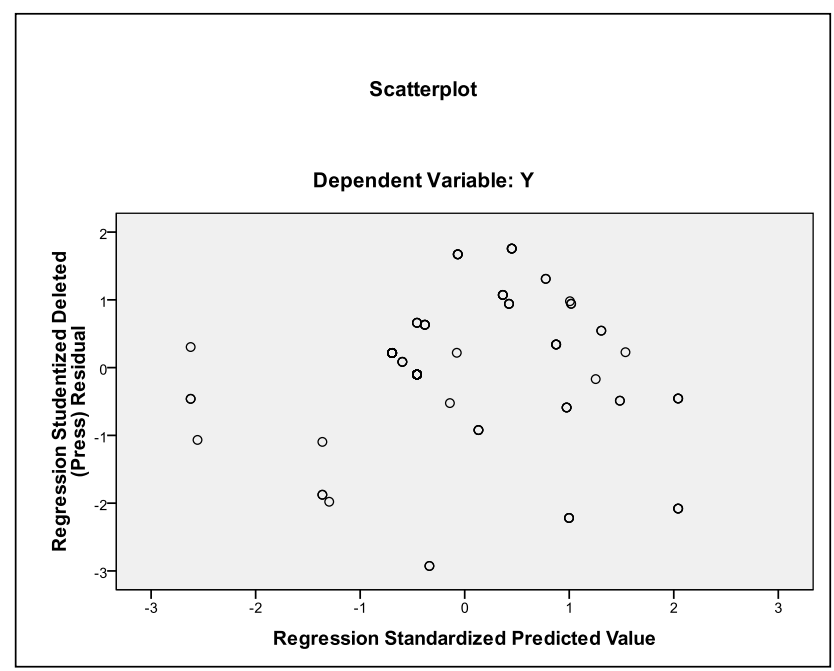

Gambar 1. UJi Heteroskedastisitas

Dari grafik di atas terlihat titik-titik menyebar secara acak dan tidak membentuk pola tertentu yang jelas, serta tersebar baik di atas maupun di bawah angka 0 pada sumbu Y. Hal ini menunjukkan bahwa tidak terjadi heteroskedastisitas pada data yang akan digunakan sebagai model regresi sehingga data layak dipakai untuk prediksi kepuasan pelanggan berdasar masukan variabel independen kualitas pelayanan.

c. Uji Normalitas

Deteksi normalitas dalam penelitian ini adalah dengan menggunakan Normal P-P Plot of Regression Standardized Residual, dimana jika data menyebar di sekitar garis diagonal grafik dan mengikuti arah garis diagonal, maka model regresi memenuhi asumsi normalitas. Namun jika data menyebar jauh dari garis diagonal, dan/ atau tidak mengikuti arah garis diagonal, maka model regresi tidak memenuhi asumsi normalitas.

Dari grafik yang ada terlihat titik-titik menyebar di sekitar garis diagonal, serta penyebarannya mengikuti arah garis diagonal. Dengan demikian dapat dikatakan bahwa data yang akan digunakan sebagai model regresi berdistribusi normal sehingga layak dipakai untuk prediksi kepuasan pelanggan berdasar masukan variabel independen kualitas pelayanan. 


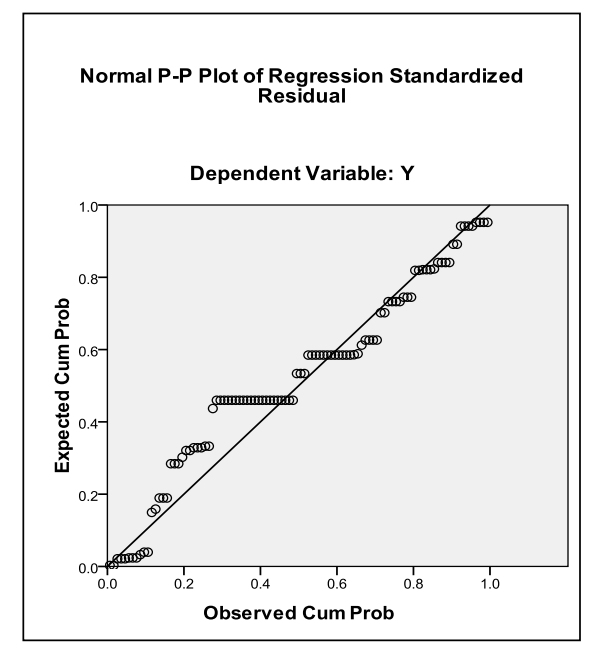

Gambar 2. Uji Normalitas

\subsection{Analisis Regresi Linear Berganda}

Analisis regresi linier berganda digunakan untuk mengetahui besarnya pengaruh tangible, reliability, responsiveness, assurance, dan empathy terhadap kepuasan konsumen dengan menggunakan rumus regresi linier berganda. Hasil analisi dengan menggunakan SPSS versi 17.00 diperoleh koefisien regresi sebagai berikut:

Tabel 3. Hasil Analisis Regresi

Coefficients $^{\mathrm{a}}$

\begin{tabular}{|c|c|c|c|c|c|c|c|c|}
\hline \multirow[b]{2}{*}{ Model } & & \multicolumn{2}{|c|}{ Coefficients } & \multirow{2}{*}{$\frac{\text { Coefficients }}{\text { Beta }}$} & \multirow[b]{2}{*}{$\mathrm{t}$} & \multirow[b]{2}{*}{ Sig. } & \multicolumn{2}{|c|}{ Collinearity Statistics } \\
\hline & & $\mathrm{B}$ & Std. Error & & & & Tolerance & VIF \\
\hline 1 & (Constant) & .408 & .237 & & 1.720 & .089 & & \\
\hline & $\overline{\mathrm{X} 1}$ & .035 & .092 & .033 & .374 & .709 & .485 & 2.061 \\
\hline & $\overline{\mathrm{X} 2}$ & .320 & .110 & .288 & 2.898 & .005 & .379 & 2.638 \\
\hline & $\overline{X 3}$ & .183 & .079 & .177 & 2.305 & .023 & .632 & 1.581 \\
\hline & $\overline{X 4}$ & .217 & .103 & .199 & 2.098 & .039 & .415 & 2.409 \\
\hline & $\overline{X 5}$ & .277 & .097 & .271 & 2.855 & .005 & .413 & 2.421 \\
\hline
\end{tabular}

Rumus regresi berganda :

$\mathrm{Y}=0.408+0.035 \mathrm{X}_{1}+0.320 \mathrm{X}_{2}+0.183 \mathrm{X}_{3}+0.217 \mathrm{X}_{4}+0.277 \mathrm{X}_{5}+0.237$

(masing-masing koefisie menunjukkan pengaruhnya terhadap varabel $\mathrm{Y}$ )

Hasil Koefisien Determinasi

Tabel 4. Koefisian Determinasi

Model Summary ${ }^{\mathbf{b}}$

\begin{tabular}{|l|r|r|r|r|r|}
\hline Model & $\mathrm{R}$ & R Square & $\begin{array}{c}\text { Adjusted } \\
\text { R Square }\end{array}$ & $\begin{array}{c}\text { of the } \\
\text { Estimate }\end{array}$ & $\begin{array}{c}\text { Durbin- } \\
\text { Watson }\end{array}$ \\
\hline 1 & $.806^{\mathrm{a}}$ & .649 & .630 & .48055 & 1.312 \\
\hline
\end{tabular}

Tabel menunjukkan bahwa besarnya koefisien korelasi $(\mathrm{R})$ sebesar 0.806, artinya bahwa variabel bebas yang diamati (tangible, reliability, responsiveness, assurance, dan empathy) mempunyai hubungan yang kuat dengan variabel terikat (Kepuasan pelanggan). Sedangkan nilai R Square sebesar 0.649, artinya variabel tangible, reliability, responsiveness, assurance, dan empathy mampu menjelaskan kepuasan pelanggan pada PT Summit Oto Finance cabang Surabaya sebesar 64.9\%, sementara sisanya sebesar $35.1 \%$ kepuasan pelanggan pada PT Summit Oto Finance cabang Surabaya dipengaruhi oleh faktor selain kualitas pelayanan.

\subsection{Pengujian Hipotesis}

1. Uji Signifikansi Pengaruh Simultan (Uji F)

Uji simultan atau uji F dilakukan untuk menguji signifikansi pengaruh variabel kualitas pelayanan yang terdiri atas tangible, reliability, responsiveness, assurance, dan empathy secara bersama-sama terhadap variabel kepuasan pelanggan. Hasil uji F dalam penelitian ini dapat dilihat pada tabel berikut: 


\begin{tabular}{|c|c|c|c|c|c|}
\hline \multicolumn{6}{|c|}{$\begin{array}{l}\text { Tabel 5. Uji F } \\
\text { ANOVA }^{\text {b }}\end{array}$} \\
\hline Model & $\begin{array}{l}\text { Sum of } \\
\text { Squares }\end{array}$ & df & $\begin{array}{l}\text { Mean } \\
\text { Square }\end{array}$ & $\mathrm{F}$ & Sig. \\
\hline 1 Regression & 40.144 & 5 & 8.029 & 34.768 & $.000^{\circ}$ \\
\hline Residual & 21.707 & 94 & 0.231 & & \\
\hline Total & 61.851 & 99 & & & \\
\hline
\end{tabular}

Dengan menggunakan tingkat keyakinan sebesar 95\%, $\alpha=5 \%$, ditentukan N1 (df1) dan N2 (df2). df1= $\mathrm{k}-1$, df2= n-k, dimana $\mathrm{k}$ merupakan jumlah variabel (bebas dan terikat), dan $\mathrm{n}$ merupakan jumlah sampel.

$$
\begin{aligned}
& \mathrm{N} 1=\mathrm{df} 1=\mathrm{k}-1=6-1=5 \\
& \mathrm{~N} 2=\mathrm{df} 2=\mathrm{n}-\mathrm{k}=100-6=94 \\
& \mathrm{~F} \text { tabel }=2.31
\end{aligned}
$$

Berdasarkan data di atas, nilai $\mathrm{F}$ hitung (34.768) > F tabel (2.31), sehingga $\mathrm{H}_{0}$ ditolak dan Ha diterima. diterima.

Berdasarkan hasil uji $\mathrm{F}$ di atas diperoleh nilai Sig $(0.000)<\alpha(0.05)$, sehingga $\mathrm{H}_{0}$ ditolak dan $\mathrm{Ha}$

Jadi dapat disimpulkan bahwa berdasarkan teori dan hasil statistik penelitian berdasarkan uji F, Variabelvariabel kualitas pelayanan yang terdiri dari tangible, reliability, responsiveness, assurance, dan empathy berpengaruh signifikan secara simultan terhadap kepuasan pelanggan PT. Summit Oto Finance Cabang Surabaya.

2. Uji Signifikansi Pengaruh Parsial (Uji T)

Uji T dilakukan untuk mengetahui pengaruh secara parsial dari variabel-variabel independen terhadap variabel dependen. Berdasarkan hasil pengolahan SPSS 17.00, diperoleh data pada tabel dibawah. Nilai t hitung dapat dilihat pada kolom t pada tabel tersebut. Kemudian dilakukan pengujian hipotesis dengan langkah-langkah sebagai berikut:

\begin{tabular}{|c|c|c|c|c|c|c|c|c|}
\hline \multirow[b]{2}{*}{ Model } & & \multicolumn{2}{|c|}{ Coefficients } & \multirow{2}{*}{$\frac{\text { Coefficients }}{\text { Beta }}$} & \multirow[b]{2}{*}{$t$} & \multirow[b]{2}{*}{ Sig. } & \multicolumn{2}{|c|}{ Collinearity Statistics } \\
\hline & & $B$ & Std. Error & & & & Tolerance & VIF \\
\hline 1 & (Constant) & .408 & .237 & & 1.720 & .089 & & \\
\hline & $\overline{X 1}$ & .035 & .092 & .033 & .374 & .709 & .485 & 2.061 \\
\hline & $\overline{\mathrm{X} 2}$ & .320 & .110 & .288 & 2.898 & .005 & .379 & 2.638 \\
\hline & $\overline{X 3}$ & .183 & .079 & .177 & 2.305 & .023 & .632 & 1.581 \\
\hline & $\overline{X 4}$ & .217 & .103 & 199 & 2.098 & .039 & .415 & 2.409 \\
\hline & X5 & .277 & .097 & 271 & 2.855 & .005 & .413 & 2.421 \\
\hline
\end{tabular}

Tabel 7. Uji t

Coefficients $^{a}$

a. Membandingkan $\mathrm{t}$ hitung dengan $\mathrm{t}$ tabel $\left(\mathrm{H}_{0}\right.$ diterima jika $\mathrm{t}$ hitung $\leq \mathrm{t}$ tabel, dan $\mathrm{H}_{0}$ ditolak jika $\mathrm{t}$ hitung $>\mathrm{t}$ tabel). Untuk menentukan $\mathrm{t}$ tabel, $\mathrm{df}=\mathrm{n}-\mathrm{k}=100-6=94$, dilakukan uji dua arah dengan signifikansi 0.05 , maka diperoleh $\mathrm{t}$ tabel sebesar 0.67711 .

b. Membandingkan nilai sig dengan $\alpha(0.05)\left(\mathrm{H}_{0}\right.$ diterima jika $\alpha>0.05(5 \%), \mathrm{H}_{0}$ ditolak jika $\alpha<0.05$ $(5 \%))$

Berdasarkan hasil uji $\mathrm{T}$ dari kelima variabel bebas diatas, maka dapat disimpulkan bahwa "Kualitas pelayanan yang terdiri dari tangible, reliability, responsiveness, assurance, dan empathy berpengaruh signifikan secara parsial terhadap kepuasan pelanggan PT Summit Oto Finance Cabang Surabaya" kurang terbukti kebenarannya. Hal ini dibuktikan oleh hasil penelitian yang menunjukkan bahwa variabel reliability, responsiveness, assurance, dan empathy memiliki pengaruh parsial yang signifikan terhadap kepuasan pelanggan PT Summit Oto Finance. Adapun variable $\mathrm{X}_{1}$ (Tangible) tidak berpengaruh signifikan secara parsial terhadap kepuasan pelanggan PT Summit Oto Finance cabang Surabaya.

Dari hasil uji tersebut juga dapat disimpulkan bahwa variabel $\mathrm{X}_{2}$ (Reliability) dengan nilai $\mathrm{t}$ hitung sebesar 2.898 dengan tingkat signifikansi 0.005 mempunyai pengaruh parsial signifikan yang paling dominan terhadap kepuasan pelanggan pada PT Summit Oto Finance dibandingkan dengan variabel bebas lainnya dalam penelitian ini. Selengkapnya dapat dilihat pada tabel berikut: 
Tabel 8. Hasil uji t

\begin{tabular}{cccc}
\hline Variabel & Item & t & Sig. \\
\hline Tangible & $\mathrm{X} 1$ & 0.374 & 0.709 \\
\hline Reliability & $\mathrm{X} 2$ & 2.898 & 0.005 \\
\hline Responsiveness & $\mathrm{X} 3$ & 2.305 & 0.023 \\
\hline Assurance & $\mathrm{X} 4$ & 2.098 & 0.039 \\
\hline Empathy & $\mathrm{X} 5$ & 2.855 & 0.005 \\
\hline
\end{tabular}

Dominannya variabel reliability tersebut menunjukkan bahwa tingkat kepuasan pelanggan pada PT Summit Oto Finance Cabang Surabaya dominan dipengaruhi oleh keandalan pelayanan PT Summit Oto Finance yang terdiri dari kesesuaian antara pelayanan yang diberikan dengan yang dijanjikan, penyampaian jasa secara benar dan konsisten, serta keakuratan perusahaan dalam menyimpan catatan atau dokumen konsumen.

\subsection{Pembahasan}

Hasil analisis menunjukkan bahwa kualitas pelayanan yang diberikan oleh PT Summit Oto Finance cabang Surabaya cukup memuaskan. Hal tersebut terlihat dari banyaknya tanggapan responden yang setuju dengan pernyataan dari masing-masing variabel penelitian. Dari hasil tersebut kemudian diperoleh bahwa variabel kualitas pelayanan memiliki pengaruh yang positif dan signifikan terhadap kepuasan pelanggan PT Summit Oto Finance cabang Surabaya.

Variabel $\mathrm{X}_{1}$ (Tangible), yaitu kemampuan perusahaan dalam menunjukkan eksistensinya kepada pihak eksternal. Penampilan fisik PT Summit Oto Finance dapat dilihat dari peralatan penunjang kegiatan sehari-hari, fasilitas gedung, dan kerapian penampilan karyawannya. Analisis deskriptif pada tabel 4.4 menunjukkan bahwa lebih dominan responden yang setuju dengan pernyataan bahwa variabel bukti fisik yang ditampilkan oleh PT Summit Oto Finance cabang Surabaya mempunyai penilaian yang baik. Hasil regresi pada tabel 4.13 menunjukkan bahwa variabel tangible meskipun bertanda positif tetapi tidak berpengaruh secara signifikan terhadap kepuasan pelanggan PT Summit Oto Finance cabang Surabaya. Hal tersebut bertentangan dengan teori service quality yang menyatakan bahwa seluruh dimensi variabel kualitas pelayanan memiliki pengaruh terhadap kepuasan pelanggan.

Untuk menjelaskan hal tersebut maka peneliti melakukan wawancara melalui telepon dengan beberapa responden terkait penilaian mereka terhadap variabel tangible pada pelayanan PT Summit Oto Finance. Menurut para responden penilaian terhadap variabel tangible cukup sulit dilakukan karena pelanggan sendiri jarang melakukan transaksi di kantor PT Summit Oto Finance cabang Surabaya dimana transaksi pada saat pembelian sepeda motor dan proses aplikasi dilakukan di dealer, dan proses tanda tangan kontrak dilakukan di kediaman pelanggan. Kebanyakan pelanggan mengunjungi kantor PT Summit Oto Finance hanya untuk meminta surat pengantar perpanjangan pajak, dan untuk melakukan pelunasan. Untuk transaki pembayaran pelanggan kebanyakan lebih memilih untuk melakukan transaksi melalui payment point seperti kantor POS, dealer yang ditunjuk, maupun melalui ATM terdekat. Selain jarangnya kunjungan ke kantor cabang, kontak langsung dengan karyawan marketing hanya dilakukan pada saat tanda tangan kontrak dan proses survey. Kondisi di lapangan, jika penulis amati, kondisi fisik PT Summit Oto Finance Cabang Surabaya sangat standar dimana kantor menempati bangunan ruko yang tidak terlalu besar sehingga sering terjadi antrian dan sesak pada tanggal-tanggal tertentu. Meskipun demikian, responden tetap memberikan penilaian bahwa variable tangible PT Summit Oto Finance Cabang Surabaya sudah baik. Dari fakta tersebut dihubungkan dengan kepuasan yang dirasakan oleh pelanggan, pada umumnya responden menilai kepuasan mereka terhadap kualitas pelayanan yang diberikan oleh PT Summit Oto Finance Cabang Surabaya berdasarkan variabel kualitas pelayanan selain tangible (reliability, responsiveness, assurance, dan empathy), sedangkan variabel tangible tidak begitu penting karena jarang dilakukan kontak dengan variabel tersebut sehingga variabel tangible tidak memberikan pengaruh yang signifikan bagi responden dalam menilai kepuasan terhadap pelayanan PT Summit Oto Finance Cabang Surabaya.

Variabel $\mathrm{X}_{2}$ (Reliability), yaitu kemampuan perusahaan untuk memberikan pelayanan sesuai dengan apa yang dijanjikan secara akurat dan terpercaya. Hal tersebut dapat dilihat dari penyediaan jasa yang sesuai dengan yang dijanjikan, penyampaian jasa dengan benar semenjak pertama kali, dan penyimpanan catatan/ dokumen tanpa kesalahan. Analisis deskriptif pada tabel 4.5 menunjukkan bahwa lebih dominan responden yang setuju dengan pernyataan bahwa variabel reliability yang yang diberikan oleh PT Summit Oto Finance cabang Surabaya mempunyai penilaian yang baik. Hasil regresi pada tabel 4.13 juga menunjukkan bahwa variabel Reliability memiliki pengaruh yang positif dan signifikan terhadap kepuasan pelanggan. Hasil tersebut memberikan bukti empiris bahwa kehandalan dari penyedia jasa yang ditunjukkan dengan penyampaian jasa dengan benar semenjak pertama kali, dan penyimpanan catatan/ dokumen tanpa kesalahan akan mempengaruhi kepuasan pelanggan.

Variabel $\mathrm{X}_{3}$ (Responsiveness), yaitu suatu kebijakan untuk membantu dan memberikan pelayanan yang cepat (responsif) dan tepat kepada konsumen, dengan penyampaian informasi yang jelas. Hal tersebut dapat dilihat dari penginformasian tentang kepastian waktu penyampaian jasa, kecepatan pelayanan, dan kesiapan 
karyawan dalam membantu pelanggan. Analisis deskriptif pada tabel 4.6 menunjukkan bahwa lebih dominan responden yang setuju dengan pernyataan bahwa variabel responsiveness yang yang diberikan oleh PT Summit Oto Finance cabang Surabaya mempunyai penilaian yang baik. Hasil regresi pada tabel 4.13 juga menunjukkan bahwa variabel Responsiveness memiliki pengaruh yang positif dan signifikan terhadap kepuasan pelanggan. Hasil tersebut memberikan bukti empiris bahwa daya tanggap dari penyedia jasa yang ditunjukkan dengan penginformasian tentang kepastian waktu penyampaian jasa, kecepatan pelayanan, dan kesiapan karyawan dalam membantu pelanggan akan mempengaruhi kepuasan pelanggan.

Variabel $\mathrm{X}_{4}$ (Assurance), merupakan pengetahuan karyawan terhadap produk mereka secara cepat, kesopansantunan dalam memberikan pelayanan, keterampilan dalam memberikan informasi, hingga kemampuan dalam memberikan keamanan dan menanamkan rasa kepercayaan dan keyakinan masyarakat terhadap perusahaan. Hal tersebut dapat dilihat dari kemampuan karyawan dalam menumbuhkan kepercayaan pelanggan, membuat pelanggan merasa aman dalam setiap transaksi, dan sikap sopan karyawan. Analisis deskriptif pada tabel 4.7 menunjukkan bahwa lebih dominan responden yang setuju dengan pernyataan bahwa variabel assurance yang yang diberikan oleh PT Summit Oto Finance cabang Surabaya mempunyai penilaian yang baik. Hasil regresi pada tabel 4.13 juga menunjukkan bahwa variabel Assurance memiliki pengaruh yang positif dan signifikan terhadap kepuasan pelanggan. Hasil tersebut memberikan bukti empiris bahwa jaminan dari penyedia jasa yang ditunjukkan dengan kemampuan karyawan dalam menumbuhkan kepercayaan pelanggan, membuat pelanggan merasa aman dalam setiap transaksi, dan sikap sopan karyawan akan mempengaruhi kepuasan pelanggan.

Variabel $\mathrm{X}_{5}$ (Empathy), sikap yang tulus yang diberikan kepada konsumen seperti kemudahan untuk menghubungi perusahaan, kemampuan untuk berkomunikasi langsung dengan konsumen guna memahami keinginan dan kebutuhan mereka. Hal tersebut dapat dilihat dari sikap karyawan memberikan perhatian individual kepada para pelanggan, bersungguh-sungguh memahami kebutuhan pelanggan, dan juga kesungguhan perusahaan dalam memperhatikan kepentingan pelanggan. Analisis deskriptif pada tabel 4.8 menunjukkan bahwa lebih dominan responden yang setuju dengan pernyataan bahwa variabel empathy yang yang diberikan oleh PT Summit Oto Finance cabang Surabaya mempunyai penilaian yang baik. Hasil regresi pada tabel 4.13 juga menunjukkan bahwa variabel Empathy memiliki pengaruh yang positif dan signifikan terhadap kepuasan pelanggan. Hasil tersebut memberikan bukti empiris bahwa empati dari penyedia jasa yang ditunjukkan oleh sikap karyawan memberikan perhatian individual kepada para pelanggan, bersungguh-sungguh memahami kebutuhan pelanggan, dan juga kesungguhan perusahaan dalam memperhatikan kepentingan pelanggan akan mempengaruhi kepuasan pelanggan.

\section{Kesimpulan Dan Saran \\ 4.1. Kesimpulan}

Berdasarkan hasil penelitian dan pembahasan yang telah dijelaskan, maka dapat ditarik kesimpulan sebagai berikut:

1. Penelitian menunjukkan hasil koefisien korelasi (R) sebesar 0.806, yang artinya variabel bebas yang diamati (tangible, reliability, responsiveness, assurance, dan empathy) mempunyai hubungan yang kuat dengan variabel terikat (Kepuasan pelanggan).Nilai $\mathrm{R}$ square sebesar 0.649 menunjukkan bahwa variabel tangible, reliability, responsiveness, assurance, dan empathy mampu menjelaskan kepuasan pelanggan pada PT Summit Oto Finance cabang Surabaya sebesar $64.9 \%$, sedangkan sisanya sebesar $35.1 \%$ kepuasan pelanggan pada PT Summit Oto Finance cabang Surabaya dipengaruhi oleh faktor selain kualitas pelayanan.Melalui Uji F ditemukan nilai F hitung (34.768) > F tabel (2.31), dan nilai Sig $(0.000)<\alpha(0.05)$, sehingga $\mathrm{H}_{0}$ yang menyatakan bahwa "Variabel-variabel kualitas pelayanan yang terdiri dari tangible, reliability, responsiveness, assurance, dan empathy tidak berpengaruh signifikan secara simultan terhadap kepuasan pelanggan PT. Summit Oto Finance Cabang Surabaya" ditolak dan Ha diterima.Dengan demikian dapat disimpulkan bahwa Variabel-variabel kualitas pelayanan yang terdiri dari tangible, reliability, responsiveness, assurance, dan empathy berpengaruh signifikan secara simultan terhadap kepuasan pelanggan PT. Summit Oto Finance Cabang Surabaya.

2. Hasil uji T menunjukkan bahwa nilai t hitung dari empat variabel independen yaitu Reliability (X2) 2.898, Responsiveness (X3) 2.305, Assurance (X4) 2.098, dan Empathy (X5) 2.855 lebih besar dari t tabel sebesar 0.67711 serta tingkat signifikansinya masing-masing 0.005, 0.023, 0.039, dan 0.005 lebih kecil dari $\alpha(0.05)$. Sedangkan variabel Tangible (X1) memiliki t hitung sebesar 0.374 (lebih kecil dari t tabel 0.67711), dan nilai signifikansi sebesar 0.709 (lebih besar dari a 0.05). Dengan demikian dapat disimpulkan bahwa variabel kualitas pelayanan yang terdiri dari reliability, responsiveness, assurance, dan empathy berpengaruh signifikan secara parsial terhadap kepuasan pelanggan PT. Summit Oto Finance Cabang Surabaya. Sedangkan variabel tangible tidak memiliki pengaruh yang signifikan secara parsial, artinya setiap perubahan nilai variabel tangible secara parsial tidak akan berpengaruh terhadap kepuasan pelanggan.Dari hasil uji tersebut juga dapat disimpulkan bahwa variabel $\mathrm{X}_{2}$ (Reliability) mempunyai 
pengaruh parsial yang paling signifikan terhadap kepuasan pelanggan pada PT Summit Oto Finance dengan nilai thitung paling besar (2.898) dan tingkat signifikansi 0.005 (dibawah nilai $\alpha$ ) .

\subsection{Saran}

Berdasarkan hasil penelitian dan pembahasan yang telah dijelaskan, dalam rangka meningkatkan kepuasan pelanggan melalui peningkatan dimensi kualitas pelayanan penulis memberikan beberapa saran yang mungkin dapat dijadikan pertimbangan bagi PT Summit Oto Finance cabang Surabaya sebagai berikut:

1. Dimensi reliability harus senantiasa dijaga dan ditingkatkan karena merupakan dimensi dari kualitas pelayanan yang pengaruhnya paling besar terhadap kepuasan pelanggan, dan pada penelitian ini merupakan dimensi dimana jumlah responden yang menilai bahwa kehandalah pelayanan PT Summit Oto Finance cabang Surabaya kurang baik lebih banyak dibandingkan dengan dimensi kualitas pelayanan yang lainnya.

2. Dimensi responsiveness, assurance, dan empathy juga perlu untuk senantiasa ditingkatkan karena dimensi tersebut juga memiliki pengaruh yang positif terhadap kepuasan pelanggan PT Summit Oto Finance cabang Surabaya.

3. Untuk dimensi Tangible, meskipun berdasarkan hasil uji $\mathrm{T}$ tidak berpengaruh secara parsial terhadap kepuasan pelanggan, hendaknya manajemen PT Summit Oto Finance dimasa-masa mendatang tetap mempertimbangkan untuk memiliki gedung perkantoran yang representatif dengan fasilitas ruangan yang memadai, seperti ruang tunggu yang luas dan nyaman, tempat parkir yang luas, dan senantiasa memperhatikan kebersihan ruangan. Selain itu bisa juga dipertimbangkan untuk memberikan layanan electronic account checking (fasilitas pengecekan akun customer via website yang berisi jadwal dan status pembayaran yang dilengkapi dengan sistem keluhan dan saran) dimana pada jaman yang serba canggih seperti ini internet telah menjadi begitu akrab di kalangan masyarakat. Selain itu, melalui fasilitas tersebut perusahaan dapat lebih mendekatkan diri kepada pelanggannya serta pelanggan dapat menyampaikan keluhan maupun pertanyaannya dengan lebih praktis dan efektif. Sebagaimana yang dialami oleh pelanggan dimana kadangkala terjadi offline system yang mengakibatkan pembayaran yang dilakukan oleh pelanggan melalui kantor POS maupun ATM terlambat masuk di sistem PT Summit Oto Finance dan kemudian mengakibatkan munculnya denda karena dianggap sebagai keterlambatan pembayaran. Melalui fasilitas electronic account checking tersebut pelanggan dapat mengakses akun kontrak nya sendiri dan memeriksa jadwal pembayaran atau jatuh tempo dan apakah pembayaran yang dilakukan telah masuk ke sistem PT Summit Oto Finance. Dengan demikian perusahaan juga mampu menunjukkan kecanggihan dan modernitas sistem yang dimiliki kepada pelanggannya sehingga dapat menjadi nilai tambah dalam meningkatkan kepuasan pelanggan.

\section{Daftar Pustaka}

Gusmao, Matilde Marques Da Costa. 2010. Pengaruh Layanan Jasa Perbankan Terhadap Kepuasan Nasabah Pada PT Bank BNU Dili Timor Leste

Iqbal, B. M. 2013. Analisa Pengaruh Kualitas Pelayanan Terhadap Kepuasan Konsumen Pada PT Adira Quantum Multifinance Cabang Makassar.

Kotler, Philip. 2002. Manajemen Pemasaran, Edisi Milenium Jilid 2. Jakarta: Prenhallindo

Kotler, Philip. 2007. Manajemen Pemasaran, Edisi 12 Jilid 1 (Benyamin Molan, Penerjemah, 2009). Jakarta: PT.Indeks

Lovelock, Christopher H. dan Wright, Lauren K. 2005. Manajemen Pemasaran Jasa. Jakarta: Indeks

Kuswadi. 2004. Cara Mudah Memahami Angka dan Manajemen Keuangan. Yakarta: PT.Elex Media Komputindo.

Lupiyoadi, Rambat dan Hamdani, A. 2006 Manajemen Pemasaran Jasa. Jakarta: PT.Salemba Empat.

Manullang, Ida. 2008. Pengaruh Kualitas Pelayanan Terhadap Kepuasan Pelanggan Jasa Penerbangan PT. Garuda Indonesia Airlines di Bandara Polonia Medang.

Munir, Misbachul. 2013. Pengaruh Kualitas Pelayanan Terhadap Kepuasan Pelanggan PT Gas Negara (Persero) Tbk SBU Distribusi Wilayah II Penjualan Area Surabaya-Gresik

Parasuraman. A, Zeithaml. VA, Berry. LL. 1985. "A Conceptual Model of Service Quality and Its Implications for Future Research". The Journal Of Marketing

Peter, J.H., 2003. Service Management in Managing The Image. Jakarta: Trisakti University.

Rangkuti, Freddy. 2003. Measuring Customer Satisfaction (Cetakan Ketiga). Jakarta: PT.Gramedia Pustaka Utama.

Santoso, Singgih. 2000. Buku Latihan SPSS Statistik Parametrik. Jakarta: PT Elex Media Komputindo.

Sugiyono. 2006. Metode Penelitian Administrasi Dilengkapi dengan Metode R\&D, Cetakan Ke-14. Bandung: CV.Alfabeta.

Tjiptono, Fandy. 2005. Prinsip-Prinsip Total Quality Service. Yogyakarta: Penerbit Andi dan Chandra, Gregorius. 2007. Service, Quality and Satisfaction (Edisi 2). Yogyakarta: Penerbit Andi.

Umar, Husein. 2005. Metode Penelitian untuk Skripsi dan Tesis Bisnis, Jakarta: PT.Raja Grafindo Persada. 